\title{
Using Health Coaching to Improve Glycemic Control in African-American Diabetics: An Integrative Review
}

\author{
Larider Ruffin*, Brenda Lee Douglass, Cecilia Boyd, Shawn Denning and Tara Crowell \\ Stockton University, USA \\ *Corresponding author: Larider Ruffin, Stockton University, 101 Vera King Dr Galloway, NJ 08205, USA \\ To Cite This Article: Larider Ruffin, Using Health Coaching to Improve Glycemic Control in African-American Diabetics: An Integrative Review. \\ 2020 - 9(6). AJBSR.MS.ID.001456. DOI: 10.34297/AJBSR.2020.09.001456.
}

Received: 䟧July 13, 2020; Published: 畊 August 14, 2020

\begin{abstract}
Background: Diabetes continues to affect our population. As a complex disease, diabetes requires multifactorial risk-reduction strategies for appropriate glycemic control. While type II diabetes remains a global epidemic capable of being traced back to rapid increases in physical inactivity and obesity, type I diabetes is characterized by autoimmune destruction of beta cells in the pancreas. Diabetes is currently the 3rd leading cause of death in the US and the 7th leading cause of death worldwide. While the entire population is at risk, African Americans bear a disproportionate burden from diabetes and its complications. Diabetes remains very costly and places a strain on the national healthcare expenditure. Diabetes selfmanagement education (DSME) is essential to successful diabetes treatment and complication prevention. However, diabetes management requires daily patient involvement and some specific skills. Health coaching has been very effective in assisting patients with skills to self-manage. There is increasing evidence of the effectiveness of health coaching in terms of patient self-efficacy, adherence to treatment, behavioral changes, health service utilization, and health outcomes.
\end{abstract}

Purpose: To appraise the effectiveness of health coaching as a strategy to improve glycemic control among African American diabetics.

Method: This is an integrative review of the literature, which includes a synchronized review of experimental and non-experimental research to appraise this diabetes epidemic.

Outcomes: Health coaching is among the most effective strategies to restrain this current diabetes epidemic. This integrative review articulates gaps in health care disparities, while capitalizing on a cost-effective, evidence-based approach to making a positive turn on diabetes.

\section{Introduction}

Diabetes is a complex, chronic and progressive illness requiring continuous medical care with multifactorial risk-reduction strategies beyond glycemic control [1]. Diabetes is characterized as a group of metabolic diseases marked by high levels of blood glucose resulting from problems in insulin production, insulin use, or both (Winjun, 2017). [2] estimate there are more than 500 million prevalent cases of Type 2 Diabetes worldwide in 2018, compared to 422 million in 2014 and 108 million in 1980 (World Health Organizations [WHO], 2018). According to CDC, 2018) 30.3 million Americans currently have diabetes and 84.1 million adults have prediabetes. The incidence of African-Americans who are at risk for prediabetes has been on the rise, contributed to multiple risk factors such as obesity, family history of diabetes, and hypertension Centers for Disease Control and Prevention [(CDC), 2018]. Recent statistics suggest newly diagnosed cases of Type I and Type II diabetes account for 1.5 million yearly with the largest concentration being in American Indians and African-Americans (CDC, 2018).

This emerging global diabetes epidemic related to type II diabetes can be traced back to rapid increases in physical inactivity 
and obesity (ADA, 2018). New cases of type I diabetes are rising by $3.4 \%$ per year across Europe, which implies the incidence could double in the next 20-years should the trends continue (Patterson et al., 2018). Diabetes is associated with an increased risk for a number of serious, sometimes life-threatening complications that should not be ignored [3]. The rates of diagnosed diabetes in adults is currently $12.1 \%$ in African-Americans compared to $7.4 \%$ in nonHispanic Whites (CDC, 2018). This gap poses a disproportionate burden on the African-American population. Evidence-based strategies are needed to effectively manage diabetes and prevent its complications. While there are substantial data on diabetes and glycemic control, there is a need for a general review of the existing literature for practice change recommendations. The purpose of this integrative review is to appraise the literature on health coaching to determine its effectiveness as a strategy to improve glycemic control among African-American diabetics.

\section{Type I vs. Type II Diabetes}

Type I diabetes is characterized by an absolute insulin deficiency resulting from an autoimmune destruction of the beta islet cells within the pancreas [4]. As a result, individuals with type I diabetes require lifelong insulin replacement. The onset of symptoms in Type I diabetes is typically presented with an acute onset of abrupt symptomology. Type II diabetes is associated with hyperglycemia and insulin resistance as a result of impaired insulin secretion evidenced by a process that takes years to develop [ 4 and 5].

In 2015, diabetes affected approximately 30.3 million U.S. citizens, of which approximately 1.25 million of those patients suffering from Type I diabetes (ADA, 2018). The incidence of Type I diabetes was 19.7 per 100,000 in children under 10 and 18.8 per 100,000 in people 10 and older representing $5 \%$ of all diabetes cases [4]. Type II diabetes is strongly associated with lower socioeconomic status and ethnic minorities [6]. This is evidenced among the African-American population where pediatric male persons were more likely found to be diagnosed with type I diabetes, whereas, African-American female pediatric patients who were overweight were more likely to be diagnosed with type II diabetes [7]. The CDC projected $40 \%$ of the U.S. population suffers from diabetes and $50 \%$ of minority populations will be affected within their lifetime secondary to rising rates of obesity [4].

\section{Health Coaching and Diabetes}

Health coaching refers to health care partnership with an individual to influence behavioral modifications, health care education, support and goal setting to promote optimal wellbeing [3]. Health coaching for the management of diabetes is an emerging role that facilitates self-care, behavioral changes, and offers frequent follow up and support [8]. The health coaching model continues to be utilized in various health care setting as a diabetes self-management intervention strategy [9]. Health coaching represents an opportunity to address psychosocial wellbeing in addition to the emphasis on glucose management and physical health, suggested [9]. Similarly, [8] reported health coaching to be an effective intervention for improving glycemic control among diabetic patients.

\section{Diabetes and African-Americans}

A growing body of research supports the fact that AfricanAmericans bear a disproportionate burden from diabetes and its complications (CDC, 2018). Evidence supporting differences include higher prevalence rates found to be as high as $80 \%$ of African-American adults more likely than White adults being diagnosed with diabetes (CDC, 2018). The African-American population was noted to have worse diabetes control and higher rates of complications when compared to the general population (ADA, 2018). Differences between African-Americans and Whites in the areas of socioeconomic, psychosocial, and behavioral factors are linked with diabetes to some degree (NIH, 2018). African-Americans with diabetes have a higher rate of comorbid complications such as retinopathy, microalbuminuria, end stage renal disease, lower extremity amputation, and mortality compared with Caucasians (ADA, 2018).

\section{Glycemic Control}

The term glycemic control refers to hemoglobin A1C (HbA1C) less than $7 \%$ to prevent the onset and progression of microvascular complications [10]. Optimal glycemic control as associated with reduced diabetic complications and improved health outcomes [11]. For example, for every $1 \%$ reduction is $\mathrm{HbA1C}$, there was an associated 35\% reduction in severe/life threatening complications associated with diabetes at the 20-year mark [12]. Given the array of treatment modalities and the complexity of diabetic control, minority persons are less likely to have adequate glycemic control [12]. In fact, only $52 \%$ of blacks managed with medication demonstrated a HbA1C of less than $7.0 \%$ compared with $57 \%$ of whites [12]. This lack of glycemic control results in a disproportional burden of diabetic complications on minority populations [11]. Glycemic control is dependent upon high level health literacy, selfcare management education, and medication adherence [13].

\section{Self-Care Management Education}

Diabetes self-care management education (DSME) is the cornerstone for adequately treating diabetes (ADA, 2018). Diabetes requires patient adherence to medication and lifestyle regimens [12]. According to Reyes et al. [14], diabetes patients with limited income tend to face many challenges for DSME such as: difficulty translating provider advice into concrete self-management tasks, strong emotional reactions, depression, comorbidities, balancing 
day-to-day life obligations, and self-management. Goose found that African-American and Hispanic individuals with diabetes to be least likely to be compliant with their prescribed diets, blood glucose testing, and smoking due to lack of disease specific education. To improve health outcomes and address disparities among, education for self-care management is of importance to optimizing healthcare outcomes in persons with diabetes.

Education through use of telephone contact offers a means supporting improved self-care management. Ruddock et al. [15] indicate telephone interventions with supportive feedback are associated with positive outcomes and found a $0.4 \%$ reduction in HbA1C when initiated telephone support and encouragement among African-Americans and Hispanics. It was further surmised that a multidisciplinary team who provided personalized feedback to the patients was associated with the greatest success. Lynch et al. [16] found patients who received their "LIFE" intervention teaching self-monitoring and goal setting over 18-hours of classes with weekly peer support telephone calls were 2.2 times more likely to have significantly reduced $\mathrm{HbA1C}$ levels compared to the control groups.

To further support self-management education, [17] found motivational intervention to be associated with a BMI reduction of 2-points, and a drastic reduction of their fasting blood sugars at 3-months. While researchers who conducted formalized education and telephone interviews noted success in lifestyle modification and improved blood glucose levels, internet and social media interventions were unable to achieve such results [15]. Peer education was associated with $0.55 \%$ to $1.23 \% \mathrm{HbA} 1 \mathrm{C}$ reduction while increased physical activity and dietary compliance yield to an average of $1.2 \% \mathrm{HbA} 1 \mathrm{C}$ reduction leading to improved glycemic control [18]. Empowering the patients towards improved self-care management has been well documented [15].

Patient non-adherence to prescribed management plans has long been a barrier to achieving diabetic control (Polonsky \& Henry, 2016). [19], found that $43 \%$ of persons with diabetes did not achieve optimal goals and only about $10 \%$ followed lifestyle modifications. Multiple studies have initiated interventions utilizing different types of professionals to fulfill the role of health coach for diabetic patients. One study found HbA1C results were improved with more gainful strides in patients who received health coaching over those who did not [20]. Moreover, patients who received health coaching from trained medical assistants were twice as likely to achieve HbA1C control than the control group [19]. The roles of the health coach include self-management support, bridge the gap between clinicians and patients, help patients navigate the healthcare system, provide emotional support and continuity of care [Appendix A].

\section{Cultural Sensitivity}

Cultural sensitivity and understanding are important assets when counseling patients with diabetes. A lack of cultural understanding is associated with mistrust of their healthcare provider [21]. Many groups, particularly African-Americans, consider the utilization of insulin as a failure to control, gain adequate control of diabetes, and refrain from being transparent with family and friends due to perceived social stigma [22]. Overcoming low health literacy and incorporating family are associated with improved patient compliance and family provides significant influence on treatment adherence and perceptions of treatment plan modalities [21]. Therefore, it is important to incorporate cultural competency in the care of the diabetic patient.

\section{Healthy People 2020 Goals}

Healthy People 2020, a national initiative of the United States Department of Health \& Human Services (USDHHS) has 16 diabetes-related objectives including reducing the annual number of newly diagnosed cases of diabetes and increasing prevention behaviors in persons at high risk for diabetes or with prediabetes (USDHSS, 2018). Reducing disease risk, incidence, burden, and economical impact, while improving quality of life and outcomes are among the top priorities. The health coaching model has the ability to address these objectives by fulfilling the specific roles of the health coach [Appendix B]. Among the 16 published goals found on Healthy People 2020, five could be directly applicable to this evidence-based review. These were noted to be as follow:

a. Increase the proportion of diabetics to perform daily blood glucose testing from $64 \%$ in 2008 to $70.4 \%$ in 2020 .

b. Increase proportion of diabetics who have HbA1C assessed at least 2-times per year from $64.6 \%$ in 2008 to $71.1 \%$ in 2020 .

c. Increase the proportion of the population with a $\mathrm{HbA} 1 \mathrm{C}$ of less than 7 .

d. Decrease the proportion of the population with HbA1C greater than 9 from $18 \%$ in 2008 to $16.2 \%$ in 2020.

e. Reduce diabetic death rate from 74 per 100,000 deaths in 2007 to 66.6 per 100,000 deaths in 2020 .

\section{Methodology}

The authors reviewed articles that support the health coaching model to address these five National goals - increase blood glucose testing, increase the proportion of diabetics with a semi-annual HbA1C, increase the proportion of diabetics with HbA1C less than 7.0, decrease the proportion with HbA1C higher than 9.0, and reduce diabetes related deaths. Hence, the first step for evidencebased practice is the development of the clinical question utilizing 
the PICO (population, intervention, comparison, outcomes) format (Melnyk \& Fineout-Overholt, 2019). The PICO question that drives the search for evidence was: (P) In African American individuals with suboptimal diabetes management (I) is health coaching an effective strategy to improve diabetes glycemic control (C) when compared to traditional diabetes management without health coaching effective $(0)$ to improve glycemic control?

A literature search was conducted to comprise of databases such as PubMed, MEDLINE, PsychINFO, Cumulative Index of Nursing and Allied Health Literature (CINAHL), Cochrane, and Academic Search complete databases. Keywords on topics of Diabetes, Type II Diabetes, Type I Diabetes, Health Coaching, Glycemic Control, African-Americans, Black Americans were utilized. Quantitative and qualitative studies, opinion reports and reviews related to diabetes and health coaching published in the English language in the past five years $(2013$ - 2018) were included in this review. Exclusion criteria were non-English languages, studies published prior to 2013, and studies unrelated to diabetes. A total of 15,307 articles were found of which 241 potentially relevant citations were considered. Upon title review, 67 citations were identified as duplicate and therefore excluded. Out of 174 articles to consider, 97 articles were excluded on abstract review leaving 77 potentially relevant articles. A total of 67 articles were excluded on full review, leaving a final count of 10 eligible articles to integrate in this review [Appendix A].

The selection of evidence for this integrative review have been critically appraised by two of the authors independently using the Critical Appraisal Skills Programme (CASP) tools, which is a combination of tools depending on the type of study identified. Data appraisal focused on the validity, reliability, and rigor of the study. The appraisal process was completed using the CASP tool to better understand whether to include or exclude an article (Complete data appraisal is available here). Evidence synthesis was completed using the appraised studies (Whittemore \& Knafl, 2005). The data extraction tool utilized is an evidence-based table that included citations, study purpose, methodology and design, results and discussion, and levels of evidence [Table I].

Table 1: Inclusion table.

\begin{tabular}{|c|c|c|c|c|c|}
\hline Number & Citation & Purpose & Methods/ Design & Results & Level of Evidence \\
\hline 1 & $\begin{array}{l}\text { Bollyky, J.B., Bravata, D., Yang, J., Wil- } \\
\text { liamson, M., \& Schneider, J. (2018). } \\
\text { Remote Lifestyle Coaching Plus a } \\
\text { Connected Glucose Meter with Cer- } \\
\text { tified Diabetes Educator Support } \\
\text { Improves Glucose and Weight Loss } \\
\text { for People with Type } 2 \text { Diabetes. } \\
\text { Journal of Diabetes Research, doi: } \\
\text { 10.1155/2018/3961730 }\end{array}$ & $\begin{array}{l}\text { To determine if con- } \\
\text { necting health de- } \\
\text { vices with lifestyle } \\
\text { coaching can pro- } \\
\text { vide and improve } \\
\text { support for people } \\
\text { with type II diabe- } \\
\text { tes. }\end{array}$ & $\begin{array}{l}\text { This study randomized } \\
330 \text { participants. } 75 \\
\text { participants had no in- } \\
\text { terventions, } 115 \text { partic- } \\
\text { ipants used a connected } \\
\text { scale, } 73 \text { used a scale } \\
\text { plus lightweight coach- } \\
\text { ing, and } 67 \text { used a scale } \\
\text { plus intense coaching } \\
\text { for } 12 \text { weeks. }\end{array}$ & $\begin{array}{l}\text { The Livongo participants improved blood } \\
\text { glucose control and had a mean decrease } \\
\text { in HbA1c from } 8.5 \% \text { to } 7.5 \% \text {. The mean } \\
\text { weight loss and blood glucose were higher } \\
\text { in the intensive compared with the light- } \\
\text { weight coaching. Weight change (lbs.): }-6.4 \text {, } \\
-4.1 \text {, and }-1.1 \text {, resp., } p=0.01 \text { ). Blood glu- } \\
\text { cose change (mg/dL):- }-19.4,-11.3 \text {, and }-2.9 \text {, } \\
\text { resp., } p=0.003 \text {. }\end{array}$ & Level II \\
\hline 2 & $\begin{array}{l}\text { Chlebowy, D. O., El-Mallakh, P., My- } \\
\text { ers, J., Kubiak, N., Cloud, R., \& Wall, } \\
\text { M. P. (2015). Motivational Interview- } \\
\text { ing to Improve Diabetes Outcomes } \\
\text { in African-Americans Adults with } \\
\text { Diabetes. Western Journal of Nursing } \\
\text { Research, 37(5); 566-580. }\end{array}$ & $\begin{array}{l}\text { To examine the ef- } \\
\text { fect of motivational } \\
\text { interviewing inter- } \\
\text { vention (MII) in Af- } \\
\text { rican-American par- } \\
\text { ticipants with Type } \\
\text { II diabetes mellitus. }\end{array}$ & $\begin{array}{l}\text { This was a controlled } \\
\text { trial which was con- } \\
\text { ducted over 3-months. } \\
\text { The study included } 62 \\
\text { participants. Data was } \\
\text { collected at baseline } \\
\text { and at the 3-month } \\
\text { mark. The study focused } \\
\text { on medication use, glu- } \\
\text { cose monitoring, and } \\
\text { physical activity. The di- } \\
\text { abetic marker used in- } \\
\text { cluded HbA1C, random } \\
\text { serum glucose, and BMI. }\end{array}$ & $\begin{array}{l}\text { Of the } 62 \text { participants } 36 \text { were in the usual } \\
\text { care group and } 26 \text { were in the MII group. } \\
\text { At the } 3 \text {-month maker only } 30 \text { participants } \\
\text { returned from the usual care group and } 12 \\
\text { from the MII group. Although there was } \\
\text { no significant difference in heath history } \\
\text { and demographic data between the par- } \\
\text { ticipants that dropped out and the ones } \\
\text { that completed. Overall MII increase the } \\
\text { amount a participant will exercise but not } \\
\text { increase medication adherence or blood } \\
\text { glucose monitoring, }\end{array}$ & Level II \\
\hline 3 & $\begin{array}{l}\text { Lynch, E. B., Liebman, R., Ventrelle, J., } \\
\text { Avery, E. F., \& Richardson, D. (2014). } \\
\text { A Self-Management Intervention for } \\
\text { African-Americans With Comorbid } \\
\text { Diabetes and Hypertension: A Pi- } \\
\text { lot RCT. Preventing Chronic Disease, } \\
\text { doi:10.5888/pcd11.130349 }\end{array}$ & $\begin{array}{l}\text { To determine the } \\
\text { effectiveness of re- } \\
\text { ducing weight in } \\
\text { diabetic and hyper- } \\
\text { tensive participants } \\
\text { using diet, physical } \\
\text { activity and peer } \\
\text { support using com- } \\
\text { munity-based group } \\
\text { intervention. }\end{array}$ & $\begin{array}{l}\text { This is a randomized } \\
\text { control trial that fol- } \\
\text { lowed African-Ameri- } \\
\text { cans with diabetes and } \\
\text { hypertensions. A total } \\
\text { of } 61 \text { participants were } \\
\text { followed for } 6 \text { months. }\end{array}$ & $\begin{array}{l}\text { The intervention participants lost a mean } \\
\text { weight of } 2.8 \mathrm{~kg}(P=.01) \text { while the control } \\
\text { participants lost } 1.1 \mathrm{~kg}(P=.05) \text {. The inter- } \\
\text { vention participants reduced their HbA1c } \\
\text { by } 0.5 \%(P=.05) \text {. The control group did } \\
\text { not have a significant difference in HbA1c } \\
\qquad(P=.10)\end{array}$ & Level II \\
\hline
\end{tabular}




\begin{tabular}{|c|c|c|c|c|c|}
\hline 4 & $\begin{array}{l}\text { Moskowitz, D., Thom, D. H., Hessler, } \\
\text { D., Ghorob, A., \& Bodenheimer, T. } \\
\text { (2013) Peer coaching to improve di- } \\
\text { abetes self-management: which pa- } \\
\text { tients benefit most? Journal of Gener- } \\
\text { al Internal Medicine, 28(7); 938-942. }\end{array}$ & $\begin{array}{l}\text { To evaluate if peer } \\
\text { health coaching on } \\
\text { HbA1C can by mod- } \\
\text { ified with diabetes } \\
\text { control. }\end{array}$ & $\begin{array}{l}\text { A sub-group analysis of } \\
\text { RTC was used to con- } \\
\text { duct this study. A total } \\
\text { of } 299 \text { patients with } \\
\text { diabetes who attend- } \\
\text { ed public health clin- } \\
\text { ics participated. There } \\
\text { were different levels of } \\
\text { health coaching. The } \\
\text { coaching was modified } \\
\text { to the participant's level } \\
\text { of self-management and } \\
\text { medication adherence. }\end{array}$ & $\begin{array}{l}\text { The peer health coaching group had a } \\
\text { greater effect in lowering HbA1C than the } \\
\text { usual care group. The participants with } \\
\text { "low" self-management had an increase } \\
\text { of } 0.3 \% \text { in HbA1C in the usual group. The } \\
\text { health coaching group had a decrease of } \\
-0.9 \% \text { in HbA1C. Participants with "low" } \\
\text { medication adherence had an increase of } \\
0.5 \% \text { in A1c in the usual group. The health } \\
\text { coaching group had a decrease of - }-1.3 \text { in } \\
\text { HbA1C. }\end{array}$ & Level II \\
\hline 5 & $\begin{array}{l}\text { Odnoletkova, I., Goderis, G., No- } \\
\text { bels, F., Fieuws, S., Aertgeerts, B., } \\
\text { Annemans, L., \& Ramaekers D. } \\
\text { (2016). Optimizing diabetes con- } \\
\text { trol in people with Type } 2 \text { diabetes } \\
\text { through nurse-led telecoaching. Dia- } \\
\quad \text { betic Medicine, 33(6); 777-785. }\end{array}$ & $\begin{array}{l}\text { To evaluate the ef- } \\
\text { fectiveness of tele- } \\
\text { coaching interven- } \\
\text { tion from nurses of } \\
\text { participants with } \\
\text { type II diabetes and } \\
\text { other modifiable } \\
\text { risk factors. }\end{array}$ & $\begin{array}{l}\text { This was a RTC with } \\
\text { participants that take } \\
\text { hypoglycemic medica- } \\
\text { tion. The data was taken } \\
\text { at baseline, } 6 \text { months, } \\
\text { and } 18 \text { months. The } \\
\text { outcomes of this study } \\
\text { focused on were total } \\
\text { cholesterol, LDL, HDL, } \\
\text { triglycerides, blood } \\
\text { pressure, BMI, and } \\
\text { HbA1c. }\end{array}$ & $\begin{array}{l}\text { There were } 287 \text { participants in the study } \\
\text { that received usual care. The baseline } \\
\text { HbA1c }=53 \text { and } 63 \text { in the elevated HbA1c } \\
\text { subgroup. At the } 6 \text {-month mark and in fa- } \\
\text { vor of the telecoaching group, the HbA1c } \\
\text { was }-2 \mathrm{mmol} / \mathrm{mol} \text { and }-4 \mathrm{mmol} / \mathrm{mol}, \mathrm{BMI} \\
\text { was }-0.4 \mathrm{~kg} / \mathrm{m} \text {, total cholesterol was }-6 \mathrm{mg} / \\
\mathrm{dl} \text {. The intervention group increased by } \\
8.9 \% \text { and decreased by } 1.3 \% \text { in the control } \\
\text { group. At the } 18 \text {-month mark the differ- } \\
\text { ence in HbA1c was }-2 \mathrm{mmol} / \mathrm{mol} \text { overall } \\
-4 \mathrm{mmol} / \mathrm{mol} \text { in the elevated HbA1c sub- } \\
\text { group. }\end{array}$ & Level II \\
\hline 6 & $\begin{array}{l}\text { Ruddock, J. S., Poindexter, M., Gary- } \\
\text { Webb, T. L., Walker, E. A., \& Davis, } \\
\text { N. J. (2016). Innovative strategies to } \\
\text { improve diabetes outcomes in disad- } \\
\text { vantaged populations. Diabetic Med- } \\
\text { icine, 33(6); 723-733. }\end{array}$ & $\begin{array}{l}\text { To research different } \\
\text { strategies that im- } \\
\text { prove diabetic out- } \\
\text { comes in patients of } \\
\text { low socio-economic } \\
\text { status. }\end{array}$ & $\begin{array}{l}\text { A comprehensive liter- } \\
\text { ature review was con- } \\
\text { ducted with } 29 \text { articles } \\
\text { placed into two tables. } \\
\text { The articles focused on } \\
\text { HbA1c levels, lipid lev- } \\
\text { els, blood pressure, BMI, } \\
\text { behavioral outcomes, } \\
\text { self-monitoring of blood } \\
\text { glucose, completion of } \\
\text { self-care behaviors and } \\
\text { medication adherence. }\end{array}$ & $\begin{array}{l}\text { It was revealed that peer support, tele- } \\
\text { health, and CHW interventions do effective- } \\
\text { ly improve HbA1c control, blood glucose } \\
\text { monitoring, self- management behaviors, } \\
\text { self-care behaviors, and medication adher- } \\
\text { ence. The study was limited on cost- effec- } \\
\text { tiveness. Peer support was the most practi- } \\
\text { cal and useful for this population. }\end{array}$ & Level III \\
\hline 7 & $\begin{array}{l}\text { Ruffin, L (2017). Health Coaching } \\
\text { Strategy to Improve Glycemic Con- } \\
\text { trol in African- American Adults } \\
\text { with Type } 2 \text { Diabetes: An Integrative } \\
\text { Review. Journal of National Black } \\
\text { Nurses' Association, 28(1); 54-59. }\end{array}$ & $\begin{array}{l}\text { To examine the ef- } \\
\text { fectiveness of health } \\
\text { coaching to improve } \\
\text { type } 2 \text { diabetes in } \\
\text { African-Americans. }\end{array}$ & $\begin{array}{l}\text { This was an integrative } \\
\text { review. A total of } 9 \text { ar- } \\
\text { ticles were used for ev- } \\
\text { idence in the study. The } \\
\text { Critical Appraisal Skills } \\
\text { Programme (CASP) } \\
\text { was the tool used to ap- } \\
\text { praise the data. An evi- } \\
\text { dence table was used to } \\
\text { extract the data. }\end{array}$ & $\begin{array}{l}\text { Out of the nine articles eight showed signif- } \\
\text { icant improvement in controlling diabetes } \\
\text { using health-coaching interventions. Three } \\
\text { types of CASP tools were used to appraise } \\
\text { five randomized control trials, three cohort } \\
\text { studies, and one qualitative study. }\end{array}$ & Level III \\
\hline 8 & $\begin{array}{l}\text { Sharma, A. E., Willard-Grace, R., Hes- } \\
\text { sler, D., Bodenheimer, T., \& Thom, } \\
\text { D. H. (2016). What Happens After } \\
\text { Health Coaching? Observational } \\
\text { Study } 1 \text { Year Following a RCT. Annals } \\
\text { of Family Medicine, 14(3); 200-207. }\end{array}$ & $\begin{array}{l}\text { To examine the long- } \\
\text { term benefits of } \\
\text { health coaching in } \\
\text { a primary care set- } \\
\text { ting. }\end{array}$ & $\begin{array}{l}\text { This was a 12-month } \\
\text { RCT. The trial followed } \\
\text { patients in the primary } \\
\text { care setting with hyper- } \\
\text { tension, uncontrolled } \\
\text { diabetes, or hyperlipid- } \\
\text { emia. The participants } \\
\text { were followed for } 24 \\
\text { months from the base- } \\
\text { line to evaluate if they } \\
\text { maintained or reached } \\
\text { any goals. Chi-square } \\
\text { test and paired } t \text {-test } \\
\text { measured the goals. }\end{array}$ & $\begin{array}{l}\text { The goals included HbA1C, systolic blood } \\
\text { pressure, or LDL cholesterol. Data was col- } \\
\text { lected at the } 12 \text {-month and the } 24 \text {-month. } \\
\text { There were } 441 \text { participants and only } 290 \\
(65.8 \% \text { ) participated at } 12 \text { and } 24 \text { months. } \\
\text { The participants in the health coaching that } \\
\text { achieved their goals dropped from } 47.1 \% \\
\text { to } 45.9 \% \text { at the } 24 \text {-month mark. The goal } \\
\text { for HbA1C dropped from } 53.4 \% \text { to } 36.2 \% \text {. }\end{array}$ & Level II \\
\hline
\end{tabular}


Wayne, N., Perez, D. F., Kaplan, D. M., \& Ritvo, P. (2015). Health Coaching Reduces HbA1c in Type 2 Diabetic Patients from a Lower-Socioeconomic Status Community: A RCT. Journal of Medical Internet Research, 17(10):e224. doi:10.2196/jmir.4871

, R., Chen, E. H., Hessler, D., DeVore, D., Prado, C., Bodenheimer, T., \& Thom, D. H. (2015). Health coaching by medical assistants to improve control of diabetes, hypertension, and hyperlipidemia in low-income patients: A RCT. Annals of Family Medicine, 13(2); 130-8.
To examine the out come in the use or non-use of mobile phones to encourage health behavior changes in clients with type 2 diabetes.

To determine whether health coaching from licensed medical assistants improves the contro of hyperlipidemia, hypertension and diabetes compared with usual care.
138 patients with type

2 diabetes and $\mathrm{HbA1C}$

level $\geq 7.3 \%$. The par- There were 7 participants that were exticipants were followed cluded from the study and placed into a for 6 months and data sub-study group. Both groups reported was collected at 3 points improvements in quality of life, satisfaction (baseline, 3 months, with life, and overall mood. Both groups and 6 months). The out- reduced their HbA1c levels but there was comes measured were no significance difference at the 6-month the change of HbA1c, mark. The intervention group decreased weight, waist circumfer- their weight $(\mathrm{P}=.006)$ and waist circumference, BMI, satisfaction ence $(P=.01)$ whereas the controls did not.

with life, depression and anxiety

This is a RCT which followed 441 participants for a total of 12 months. There were 2 groups and data were collected 3 times; during the baseline, 6 months, and the 12 months marks. The data was arranged by race, ethnicity, gender, medication types and diabetes.
Level II

The participants in the health coaching group were more than likely to complete at least 1 of their goals than the usual arm participates. The coaching arm reached their composite measure goals $(46.1 \%$ vs $34.3 \% \mathrm{P}=.02$ ) and in the secondary composite measure goals $(34.0 \%$ vs $24.7 \%)$. The coached clients reached their HbA1C goal $(48.6 \%$ vs $27.6 \% \mathrm{P}=.01)$ ) and their LDL cholesterol goal $(41.8 \%$ vs $25.4 \% \mathrm{P}=$ $.04)$.

\section{Results}

Results of the integrative review of literature indicate that the coaching model may lead to improved glycemic control among African-American patients with diabetes. The studies were synthetized and critically appraised using the CASP tool. The overall results reveal that patient's accountability, overall support, and medication adherence are the core components of health coaching, which are paramount to optimal glycemic control in the AfricanAmerican population. The use of health coaching model can help to obtain the five National goals. The following examples from past research illustrate support for these statements. Specifically, Bollyky and colleagues [23] found that program participation resulted in significantly improved glycemic control. Both coaching arms had statistically significant improvement of blood glucose. Bollyky and colleagues [23] included 11\% of African-American and there was no statistical significance between ethnic groups. Similarly, [17] reported the coaching group had significantly lower HbA1C levels and significantly improved adherence to diabetes self-management compared to the other group. Chelebowy and colleagues [17] study population was $100 \%$ African-American and recommended that diabetes clinicians use an individualized approach that accommodates contextual features such as socioeconomic status and complexity of the treatment regimen when collaborating with the diabetes patient. The roles of the health coach stress the importance of these parameters.

According to Lynch et al. [16], an intensive community-based program was found to be more effective at improving glycemic control in low income African-American with diabetes. Specifically, researchers of this study of $100 \%$ African-Americans stated that included the culturally tailored education, behavioral skills along with peer support may lead to clinically significant reduction in HbA1C. Along the same lines, [24] found the level of diabetes selfmanagement to be enhanced by the health coaching model from his study that was inclusive of $30 \%$ African-Americans and found no effect modification by demographic factors. The absence of an effect of patient race/ethnicity may be explained through the linguistic concordance of patients and coaches as patients could choose their own coach [24].

Peer health coaching had a larger effect on HbA1C improvement especially when targeting high risk patients with poorly controlled diabetes. Ednoletkova et al. [25] found Nurse-led tele-coaching to help sustain glycemic control in patients with diabetes Peer support can improve clinical outcomes of $\mathrm{HbA1C}$ and was reported to be a practical and effective intervention approach to assist AfricanAmerican diabetic patients [15].

Consistent with Ruffin [3], health coaching is an effective strategy to improve glycemic control and overall quality of life of African-American patients with diabetes. This integrative review captured the effectiveness of health coaching in addressing glycemic control in African-American adults with type 2 diabetes. In addition, Wayne et al. [15] study was inclusive of 45\% African-Americans and found significant improvement in $\mathrm{HbA1C}$ for participants in the health coaching group. Health coaching in primary care appears to lead to significant benefits for poorly controlled diabetics [15]. Willard-Grace et al. [19] supported the notion that health coaching has the potential to alleviate nationwide deficiencies in glucose 
control, especially from the African-American population. The health coaching model improved glycemic control in nearly twice as many coached patients over traditional care model [19].

\section{Strength \& Limitation}

Findings from this evidence-based practice review support the modality of health coaching and offer benefits for providing assistance to African-American patients with type 2 diabetes. This integrative review has several limitations pertinent to the search criteria. Limiting the study to publications in the English language dated 2013 to 2018 excluded many landmark studies on diabetes and health coaching. There is a scarce of data on health coaching and diabetes in the African-American population. Additionally, the CASP tool was challenging as a combination of multiple subsets of tools limited to specific types of studies. Critical appraisal could have been stronger with one single tool apprising the evidence.

\section{Conclusion and Recommendations}

This evidence-based practice change project captured the effectiveness of the health coaching model in addressing diabetes in the vulnerable population. Health coaching is an important tool to address glycemic control and improve quality of life of AfricanAmerican patients with diabetes. The National diabetes goals aligned with Healthy People 2020 may be achieved by implementing the health coaching model in the care of patients with uncontrolled diabetes. As a modality for best practice, the health coaching model may be a beneficial strategy to provide added support to African-American patients with diabetes. Advanced practice nurses and physicians can implement this strategy in the primary care setting and the endocrinology specialty practice to further support patients with uncontrolled diabetes. To optimize glycemic control, patients need to have a fundamental understanding of the nature of diabetes, self-management, effective communication with clinicians, ability to navigate the healthcare system, receive optimal emotional support, and continuity of care to meet their health care goals and improve glycemic control. Randomized control trials and longitudinal studies with large sample size are required to further assess the feasibility of health coaching in the AfricanAmerican population. Considering the escalating prevalence and risk of untoward outcomes secondary to diabetes, it is imperative for additional strategies, such as health coaching, to be employed to further support and address the global diabetes threat.

\section{References}

1. American Diabetes Association (2018) Standards of medical care in diabetes. Diabetes Care 41(Supplement 1): S1-S2.

2. Kaiser A B, Zhang N, Van Der Pluijm W (2018) Global Prevalence of Type 2 Diabetes over the Next Ten Years (2018-2028). Diabetes 67(Supplement 1).

3. Ruffin L (2017) Health Coaching Strategy to Improve Glycemic Control in African-American Adults with Type 2 Diabetes: An Integrative Review. J Natl Black Nurses Assoc 28(1): 54-59.
4. Khardori R (2018) Type 1 Diabetes Mellitus. Medscape.

5. Mc Culloch D, Robertson R (2018) Pathogenesis of Type 2 Diabetes Mellitus. Uptodate.

6. Assari S, MoghaniLankarani M, Piette J D, Aikens J E (2017) Socioeconomic Status and Glycemic Control in Type 2 Diabetes; Race by Gender Differences. Healthcare (Basel) 5(4): 83.

7. Dabelea D, Stafford J M, Mayer Davis E J, D Agostino R, Imperatore G, et al. (2017) Association of Type 1 Diabetes vs Type 2 Diabetes Diagnosed During Childhood and Adolescence With Complications During Teenage Years and Young Adulthood. JAMA 317(8): 825-835.

8. Sherifali D, Viscardi V, Bai J, Ali R M(2016) Evaluating the Effect of a Diabetes Health Coach in Individuals with Type 2 Diabetes. Can J Diabetes 40(1): 84-94.

9. Pirbaglou M, Katz J, Motamed M, Pludwinski S, Walker K, et al. (2018) Personal Health Coaching as a Type 2 Diabetes Mellitus Self-Management Strategy: A Systematic Review and Meta-Analysis of Randomized Controlled Trials. Am J Health Promot 32(7): 1613-1626.

10. Keeble D S, Farland M Z, Eaddy J (2014) Glycemic Control Is an Important Consideration in Diabetes Care. Am Fam Physician 90(8): 524-526.

11. Wilmont, Sibyl Shalo BSN, RN (2014) Diabetes Trends: 20 Years of Progress and Paradox. American Journal of Nursing 114(7): Pp 18.

12. Selvin E, Parrinello C M, Sacks D B, Coresh J (2014) Trends in Prevalence and Control of Diabetes in the United States, 1988-1994 and 1999-2010. Ann Intern Med 160(8): 517-526.

13. Olesen K, Reynheim A L, Joensen L, Ridderstrale M, Kayser L, et al. (2017) Higher health literacy is associated with better glycemic control in adults with type 1 diabetes: a cohort study among 1399 Danes. BMJ Open Diabetes Res Care 5(1):e000437.

14. Reyes J, Tripp Reimer T, Parker E, Muller B, Laroche H (2017) Factors Influencing Diabetes Self-Management Among Medically Underserved Patients With Type II Diabetes. Glob Qual Nurs Res 4: 2333393617713097.

15. Ruddock J S, Poindexter M, Gary Webb T L, Walker E A, Davis N J (2016) Innovative strategies to improve diabetes outcomes in disadvantaged populations. Diabet Med 33(6): 723-733.

16. Lynch E B, Liebman R, Ventrelle J, Avery E F, Richardson D (2014) A Self-Management Intervention for African-Americans With Comorbid Diabetes and Hypertension: A Randomized Controlled Trial. Prev Chronic Dis 11: E90.

17. Chlebowy DO, ElMallakh P, Myers J, Kubiak N, Cloud R, et al. (2015) Motivational Interviewing to Improve Diabetes Outcomes in AfricanAmericans Adults with Diabetes. West J Nurs Res 37(5): 566-580.

18. Bergenstal R M, Gal R L, Connor C G, Gubitosi Klug R, Kruger D, et al. (2017) Racial Differences in the Relationship of Glucose Concentrations and Hemoglobin A1C Levels. Ann Intern Med 167(2): 95-102.

19. William Grave R, Chen E H, Hessler D, De Vore D, Prado C, et al. (2015) Health coaching by medical assistants to improve control of diabetes, hypertension, and hyperlipidemia in low-income patients: A randomized controlled trial. Ann Fam Med 13(2): 130-138.

20. Wayne N, Perez D F, Kaplan D M, Ritvo P (2015) Health Coaching Reduces HbA1C in Type 2 Diabetic Patients from a Lower-Socioeconomic Status Community: A Randomized Controlled Trial. J Med Internet Res 17(10): e224.

21. Zeh P, Sandu H, Cannaby A, Sturt J (2014) Cultural Barriers Impeding Ethnic MinorityGroups from Accessing Effective Diabetes Care Services: A Systemic Review of Observational Studies. Diversity and Equality in Health and Care (11): 9-33.

22. Rebolledo J, Arellano R (2016) Cultural Differences and Considerations When Initiating Insulin. Diabetes Spectr 29(3): 185-190. 
23. Bollyky JB, Bravata D, Yang J, Williamson M, Schneider J (2018) Remote Lifestyle Coaching Plus a Connected Glucose Meter with Certified Diabetes Educator Support Improves Glucose and Weight Loss for People with Type 2 Diabetes. J Diabetes Res 2018: 3961730.

24. Moskowitz D, Thom D H, Hessler D, Ghorob A, Bodenheimer T (2013) Peer coaching to improve diabetes self-management: which patients benefit most? J Gen Intern Med 28(7): 938-942.

25. Odnoletkova I, Goderis G, Nobels F, Fieuws S, Aertgeerts B, et al. (2016) Optimizing diabetes control in people with Type 2 diabetes through nurse-led telecoaching. Diabet Med 33(6): 777-785.

26. American Diabetes Association (2017) Fast fact: Data and statistics about diabetes

27. Centers for Disease Control and Prevention (2018) National diabetes fact sheet: National. estimates and general information on diabetes and pre-diabetes in the United States, Atlanta, Ga, US Department of Health and Human Services.

28. Mc Gloin H, Timmins F, Coates V, Boore J (2015) Exploring the potential of telephone health and wellness coaching intervention for supporting behaviour change in adults with diabetes. Journal of Diabetes Nursing 19: $394-400$.
29. National Institute of Health (2018) Factors contributing to higher incidence of diabetes for Black Americans.

30. Office of Disease Prevention and Health Promotion (2016) Heart disease and stroke. In Healthy People 2020.

31. Patterson C C, Harjutsalo V, Rosenbauer J, Neu A, Cinek O, et al. (2018) Trends and cyclical variation in the incidence of childhood type 1 diabetes in 26 European centres in the 25-year period 1989-2013: A multicentre prospective registration study. Diabetologia 62(3): 408-417.

32. Sari M I, Sari N, Darlan D M, Prasetya R J (2018) Cigarette Smoking and Hyperglycaemia in Diabetic Patients. Open access Maced J Med Sci 6(4): 634-637.

33. Sharma A E, Willard Grace R, Hessler D, Bodenheimer T, ThomD H, et al. (2016) What Happens After Health Coaching? Observational Study 1 Year Following a Randomized Controlled Trial. Ann Fam Med14 (3): 200-207.

34. World Health Organization (2017) Facts file: 10 facts about diabetes. 